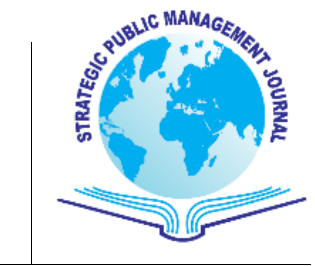

\section{Sağlık Personelinin Bilgi Sistemi İşlevlerini Kullanımları ve Örgütsel Performansa Etkisi}

\author{
Use of Information System Functions of Health Personnel and \\ Effect on Organizational Performance
}

\author{
Harun KIRILMAZ ${ }^{1}$ \\ Selma KILIC KIRILMAZ ${ }^{2}$ \\ Melike KAHRAMAN ${ }^{3}$
}

Strategic Public Management Journal Volume 4, Issue 8, pp. 62-80 December 2018 DOI: $10.25069 /$ spmj. 474458 Received: 24.10 .2018 Accepted: 06.12.2018 (C) The Author(s) 2018 For reprints and permissions: http://dergipark.gov.tr/spmj

$\ddot{\boldsymbol{O}_{z}}$

Son yıllarda bilgi teknolojilerinde (BT) yaşanan hızlı gelişmeler örgütlerin bilgiyi toplamasına, kaydetmesine ve bu bilgiyi işleyerek tekrar kullanabilmesine olanak tanımaktadır. Bu anlamda örgütlerin bilgi teknolojilerini kullanmaları, günümüzün rekabetçi ortamında rakiplerden bir adım önde olabilmek adına stratejik bir öneme sahiptir.

$\mathrm{Bu}$ araştırmanın amacı, sağlık çalışanlarının bilgi sistemi işlevleri kullanımlarının örgütsel performansa etkisinin olup olmadı̆̆ını ortaya koymaktır. Araştırmanın problemi, sağlık personelinin bilgi sistemi işlevleri kullanımlarının örgütsel performansa olan etkilerini ortaya koymaktır. Araştırma İstanbul ili Pendik ilçesinde bulunan üç adet özel hastanede yapılmıştır. Araştırmanın evrenini söz konusu hastanelerde görev yapan sağllk personeli oluşturmaktadır. Araştırmanın örnekleminin belirlenmesinde basit tesadüfi örneklem kullanılmıştır. Çalışmada veri toplama aracı olarak, Özdemir ve Dulkadir (2017) tarafindan geliştirilen ve 33 sorudan oluşan 5 'li Likert tipi ölçek kullanılmıştır. Ayrıca anket formunda, katılımcıların demografik özelliklerini belirlemeye yönelik 5 adet soru bulunmaktadır.

Çalışmadan elde edilen bulgulara göre; örgütsel performans ve BT'nin hem dışsal hem de içsel odaklaşma amaçlı işlevleri arasında pozitif yönde, anlaml, çok güçlü bir ilişki bulunmuştur. BT'nin hem dışsal hem de içsel odaklaşma amaçlı işlevlerinin örgütsel performansı pozitif yönde etkilediği görülmüş̧ür. Ayrıca, BT'nin dışsal odaklaşma amaçlı işlevlerinin kullanımı sonucunda örgütsel performans üzerinde etkili bir artı̧̧ gözlenmiş ve BT'nin içsel bütünleşme amaçlı işlevleri arttıkça çalı̧̧anların örgütsel performansı da artmıştır.

Anahtar Kelimeler: Örgütsel Performans, Bilgi Sistemleri, Sağllk Personeli.

\footnotetext{
${ }^{1}$ Doç. Dr., Sakarya Üniversitesi, Sağlık Yönetimi Bölümü, hkirilmaz@ sakarya.edu.tr

${ }^{2}$ Dr. Öğr. Üyesi, Sakarya Uygulamalı Bilimler Üniversitesi, Uluslararas1 Ticaret ve Lojistik Bölümü, selma.kirilmaz@gmail.com

${ }^{3}$ Sakarya Üniversitesi, Sağlık Yönetimi Bölümü, melikekahraman50@gmail.com
} 


\section{Abstract}

In recent years, rapid developments in information technology (IT) have enabled organizations to collect, store and reuse information. In this sense, organizations' use of information technology has a strategic prerequisite in order to be one step ahead of competitors in today's competitive environment.

The aim of this research is to determine whether the use of information system functions by health personnel is an effect on organizational performance. The problem of research is to reveal the effects of use of information system functions of health personnel on organizational performance. The research was carried out in three private hospitals located in Pendik, Istanbul. The universe of research constitutes the health personnel who are working in those hospitals. A simple random sample was used in determining the sample of research. A 5-point Likert-type scale developed by Ozdemir and Dulkadir (2017) and consisting of 33 questions was used as data collection tool in the study. In addition, there are 5 questions on the questionnaire to determine the demographic characteristics of the participants.

According to the findings obtained without working; there is a positive, significant, and very strong relationship between organizational performance and the functions of both external and internal focus of IT. It has been seen that the functions of both external and internal focus of IT have a positive effect on organizational performance. In addition, an effective increase in organizational performance has been observed as a result of the use of IT's external focus functions, and the organizational performance of employees has increased as the functions of IT for internal integration increase.

Key Words: Organizational Performance, Information Systems, Health Personnel.

\section{GíRiş}

Günümüzde teknoloji alanında yaşanan hızlı değiş̧im örgütleri de etkilemiş örgütlerin bu değişime ayak uydurmasını zorunlu kılmıştır. Bu bağlamda örgütler rakiplerinin önüne geçmek ya da onların gerisinde kalmamak adına bilgi teknolojileri kullanımını iş yapma süreçlerine dâhil etmişlerdir. Bilginin toplanması, depolanması, işlenmesi, taşınması ve verilerden yeni bilgilerin üretilmesinde bilgi teknolojilerinin rolü büyüktür. Örgütlerin kullandığı belli başlı bilgi teknolojileri arasında; İnternet, ekstranet, ofis otomasyon sistemleri, fonksiyonel bilişim sistemleri, yönetim bilişim sistemleri, karar destek sistemleri ve elektronik veri değişim sistemleri sayılabilir. Maliyet azatlımı, yeni ürün tasarımı, hizmet sunumunun kalitesinin artırımı, verimlilik artışı, tedarikçilerle, çalışanlarla ve tüketicilerle iletişim kurulması gibi örgüt için oldukça önemli konularda bilgi teknolojileri kullanımı gerekmektedir. Bilgi teknolojileri kullanımı yöneticilerin karar alma süreçlerini de etkilemektedir. Yöneticiler bilgi teknolojileri kullanımı sayesinde çok daha hızlı ve etkili kararlar alabilmektedirler.

Bilgi teknolojileri kullanımı her sektör için önemli olmakla birlikte bazı sektörler için kritik bir önem arz etmektedir. Sağlık sektörü bu sektörlerin başında gelmektedir. Sağlık teknolojileri alanında yaşanan hızlı değişim, sektördeki yoğun rekabet, bu alanda yapılan sürekli yasal düzenlemeler bilgi teknolojileri kullanımını zorunlu kılmaktadır. Bu bağlamda sağlık çalışanlarının bilgi sistemi işlevleri kullanımı konusunda olumlu bir tutum sergilemeleri ve bilgi sistemi işlevlerini etkin bir şekilde kullanmaları örgütsel performans açısından oldukça önemlidir.

$\mathrm{Bu}$ çalışmada, sağlık personelinin bilgi sistemi işlevleri kullanımlarının örgütsel performansa olan etkileri ortaya konulmaya çalışılmaktadır. Bu bağlamda ilk önce kavramsal çerçeve üzerinde durulmuş, bilişim teknolojileri, örgütsel performans ve bilgi teknolojileri kullanımının örgütsel performansa etkileri konularında 
literatür taraması yapılmıştır. Daha sonra, metodoloji bölümünde, amaç, evren ve örneklem, veri toplama tekniği, verilerin analizi ve değerlendirilmesi, araştırmanın modeli ve hipotezleri ve güvenirlik analizleri açıklanmıştır. Bulgular bölümünde ise katılımcıların sosyo-demografik özelliklerine göre farklılıkları incelenmiş, bilgi teknolojileri ve örgütsel performans ilişkisi için elde edilen bulgular ortaya konulmuştur. Son olarak araştırmanın bulguları sonuçlar kısmında değerlendirilmiştir.

\section{KAVRAMSAL ÇERÇEVE}

\subsection{Bilişim Teknolojileri}

Bilişim; bilgi ve teknolojinin birlikte kullanılarak üretilen sonuçlar olarak kısaca tarif edilebilir. Bilişim teknolojisi, bilginin toplanmasında, depolanmasında, işlenmesinde, bilgisayarlar aracılı̆̆ıyla bir yerden bir yere iletilip kullanıcıların hizmetine sunulmasında kullanılan iletişim ve bilgisayarlar dâhil bütün teknolojileri kapsayan teknolojilerdir. Bilişim teknolojisi iletişim ve bilgisayar sistemleriyle bağlanabilen bilgi hizmetlerinin tamamı için kullanılan bir kavramdır (Özdemir, 2011: 158).

Bilgi çağı olarak bugünü biçimlendiren teknoloji devriminin temeli; bilgi, bilgisayar ve telekomünikasyon iletişim- arasında var olan ilişkiye dayanmaktadır. Mikro-elektronik teknolojisinin bu üç elemana uygulanması, bunların birbirlerine yakınlaşmasını ve birbirlerini desteklemesini sağlamıştır. Bu üç unsurdan bilgisayarlar, bilgiyi yönetmede ve işlemede daima organik bir role sahip olmuştur. Bilgisayarlar insanoğlunun karar alma işlevini desteklemek üzere zihinsel olarak birtakım hesaplamalar yapma gücünü artırma çabası ile varlık bulmuş ve giderek karmaşıklaşan sorunların çözümüne paralel olarak, sahip olduğu nitelikleri de artmıştır (Bensghir, 1996: 30).

Bilgi teknolojisi, “ana sistemlerden mikro bilgisayarlara kadar bilgisayar temelli tüm bilişim sistemleri” olarak tanımlanmaktadır (İraz, 2004: 409). Bilgi teknolojileri; kavram olarak, verilerin kayıt edilmesi, saklanması, belirli bir işlem sürecinden geçirmek suretiyle bilgiler üretilmesi, üretilen bu bilgilere erişilmesi, saklanması ve nakledilmesi gibi işlemlerin etkili ve verimli yapılmasına olanak tanıyan teknolojileri tanımlamada kullanılan bir terimdir (Bensghir, 1996: 39). Bilgi teknolojisi, günümüz işletmelerinin yaygın bileşenidir. Bilgi teknolojileri bilgisayar destekli iletişim teknolojileri, veri tabanı ve analitik yazılımı kapsar (Reddy, 2006: 18).

Bilgi teknolojileri; sesli, resimli, metinli ve sayısal verilerin elde edilmesi, işlenmesi, saklanması ve dağıtımım yürüten mikro-elektroniğe dayalı hesaplama ve iletişim teknolojilerini içerir. Bu çerçevede, başta bilgisayarlar ve bunlara destek sunan girdi ve çıktı donanımları olmak üzere faks, mikrografik, telekomünikasyon, doküman doldurma ve hazırlama makineleri ve basım makineleri vb. bilgi teknolojileri terimi içinde yer alan donanımlar olmaktadır. Bilgi teknolojileri lazer, fiber optik, ses tarayıcıları gibi iletişim teknolojilerinin gelişimine paralel olarak hızla gelişmektedir. Bilgi ve iletişim teknolojilerinin işbirliği içinde gelişmesi, bilginin üretilmesi ve akışının daha etkili ve verimli gerçekleştirilmesinde devrimsel bir değişimi sağlamıştır. Bilgi artık daha verimli ve etkili işlenebilmekte, daha hızlı ve arzu edilen biçimlerde iletilebilmektedir (Bensghir, 1996: 39).

Bilginin etkin bir şekilde oluşturulması, aktarılması, geliştirilmesi ve paylaşılmasında BT'lerin rolü tartış1lmazdır (Turan, 2009: 107). Teknolojiler örgütlerin faaliyetlerinin etkinliğini arttırma sürecinde bir araç olmaktan öte, günümüzde örgütlerin değişmesi ve dönüşmesi sürecinde katalizör görevini üstlenmişlerdir (Turan, 2009:110). İşletmelerde kullanılan ilişim teknolojilerinin kapsamı aşağıdaki gibi özetlenebilir (Elibol, 2005: 158-159):

- İnternet Kullanımı: İnternet; dünya üzerindeki milyonlarca bilgisayar ağının birbirleriyle ortak bir protokol çerçevesinde iletişim kurmasını ve bilgi kaynaklarını paylaşmasını sağlayan bilgisayar 
ağlarıdır. Bir başka tanıma göre internet; TCP/IP (Transmission Control Protocol/Internet Protocolİletişim Kontrol Protokolü/İnternet Protokolü)'yi tanıyan ağların oluşturduğu büyük bir ağdır.

- İntranet ve Ekstranet Kullanımı: İntranet, işletme çalışanları ve bölümlerini İnternet yazılımları ve standartları kullanarak birbirine bağlayan özel bir bilgisayar iletişim ağıdır. İntranet Web sitelerini diğer bilgisayar sitelerinden farklı kılan, bir koruma sistemi aracılığıyla istenmeyen kişilerin veya kullanıcıların siteye erişiminin engellenmesidir. İntranet bir şirketler topluluğuna bağlı şirketler arasında iletişim sağlarken, Ekstranet ise işletme dışından başka kişilerin kısmen kullanımına da açık durumdadır. İntranet bilişim ağlarıyla şirketler arasında insan kaynakları, muhasebe, üretim, otomasyon yazılımları çalıştırmak mümkün olduğu gibi, çeşitli veri tabanları tutmak ve belge dağıtımı gibi işlemleri de gerçekleştirmek mümkündür.

- Ofis Otomasyon Sistemleri: Ofis otomasyonu, bir ofiste yapılan rutin işlemleri ve işlevleri otomatik hale getirmek amacıyla bilgisayar teknolojisinin kullanılmasıdır. Ofis otomasyon sistemlerini, bireyler, gruplar ve örgütler arasında elektronik mesajların, belgelerin ve diğer iletişim formlarının toplanmasını, işlenmesini, kayıt edilmesini ve aktarılmasını sağlayan bilgisayar temelli bilişim sistemleri olmaktadir.

- Fonksiyonel Bilişim Sistemleri: İşletme amaçlarının yerine getirilmesi bir takım işletme fonksiyonlarının uygun bir şekilde yerine getirilmesine bağlıdır. Bu fonksiyonların etkin ve verimli bir şekilde yerine getirilmesinde bilişim sistemlerinin birçok katkıları olmaktadır. İşletmelerde kullanılan pazarlama bilişim sistemleri, üretim bilişim sistemleri, muhasebe bilişim sistemleri vb. fonksiyonel bilişim sistemleri kapsamına girmektedir.

- Yönetim Bilişim Sistemleri: Yönetim bilişim sistemleri, bir yönetim destek sistemi olup, bir işletmenin mevcut faaliyetlerinin planlanması ve kontrolü ile işletmenin gelecekteki performansının tahmin edilmesine olanak sağlayan rutin, özet raporlarının hazırlanmasını ve sunulmasını sağlamaktadır. Genel olarak yönetim bilişim sistemleri, çevre ve işletme dışı faaliyetlerden daha çok işletme içi faaliyetler üzerinde odaklanmış olup, yönetim düzeyindeki planlama, kontrol ve karar verme fonksiyonlarını desteklemektedir. Yönetim bilişim sistemleri, genel olarak ihtiyaç duydukları veriler için ticari işlem sistemlerine bağımlıdırlar.

- Uzman Sistemler: İnsanların çalışmalarını, deneyimlerini bilgisayara aktaran yapay zekâ programlarına uzman sistem adı verilmektedir. Bir uzman sistem, belirli bir alanda uzman bilgisini depolayabilir, mantıksal sonuçları takip etmek suretiyle problemleri çözebilir. Uzman sistemler deneyim ve uzmanlık gerektiren karmaşık işlerin nasıl yapılacağı konusunda yol gösteren bilgisayar uygulamalarıdır. Uzman sistemler genellikle ihtisas konularında danışılan ve karar vericiye görüş belirten bir uzman gibi çalışırlar.

- Karar Destek Sistemleri: İşletme yöneticilerinin yarı yapılandırılmış ve yapılandırılmamış kararlarına destek olmak amacıyla kullanılan bilgisayar sistemleridir.

- Elektronik Veri Değişim Sistemleri: Elektronik veri değişimi, bilgisayar ve iletişim ağları kullanılarak fatura, nakliye, fiyat listeleri, satın alma, ithalat ve ihracat belgeleri ve bunlarla benzerlik gösteren çeşitli işlemlerin iki ayrı işletme arasında elektronik değişimini sağlayan bir sistemdir. Günümüzde, bankacılık hizmetlerinde elektronik veri değişimi yoğun bir şekilde kullanılmaktadır.

Günümüzde bilişism sistemleri bir işletmenin rekabet üstünlüğü sağlamasında kritik rol oynamaktadırlar. Bilişim sistemleri alanındaki gelişmeler, bu sistemlerin lisans kullanım haklarından ve teknolojik altyap1/kalifiye işgücü yetersizliğinden kaynaklanan maliyetlerin azalması ile birlikte piyasadaki rekabet yapısının değiştirilmesi ve rekabet üstünlüğünün elde edilmesi konusunda yeni firsatlar sunmaktadır. İşletmeler bilişim sistemlerini etkin bir biçimde kullanarak; verimlilik artışı sağlayabilmekte, maliyetlerini azaltabilmekte, 
yeni ürünler, hizmetler ve süreçler geliştirerek rakiplerine karsı üstünlük elde edebilmektedir (Tekin, Zerenler ve Bilge, 2005: 117).

Bilgi teknolojileri sadece bireysel faaliyetleri içermez, yeni bilgi akışı yoluyla şirketin içinde ve dışındaki faaliyetler arasında bağlantıları kullanarak şirket yönetimini büyük bir oranda arttırır. Teknoloji, ayrıca faaliyetler arasında yeni bağlantılar yaratır ve şirketler bu durumda muhtemelen satın alıcılarını ve tedarikçilerini daha fazla koordine edebilir (Porter ve Millar, 1985: 152).

Son 20 yıl içerisinde bilgi teknolojilerinin işletmelerde veri işleme ve bilgi sağlama konularında kullanım alanlarına ilişkin önemli gelişmeler olmuştur. Bilgisayar teknolojisindeki gelişmelere bağlı olarak, veri işleme daha hızlı, güvenilir ve ucuz bir hale gelmiştir. Her geçen gün artan teknik kapasiteleri, azalan maliyetleri ve kullanım kolaylıkları ile bilgi teknolojilerinden işletmelerde çok yaygın olarak faydalanılmaktadır (Yıldız, 2008: 217).

\section{2. Örgütsel Performans}

Performans, belirlenen koşullara göre bir işin yerine getirilme düzeyi veya işgörenin davranış biçimi olarak tanımlanabilir (Bingöl, 2006: 321). Performanstan bahsedebilmek için hedeflenen bir amacın ve bu amaca ulaşmak için standartların olması gerektiğini söylemek mümkündür. Bu çerçevede performans, amaca yönelik tespit edilmiş standartlara uygun davranışların gösterilmesi ve hedefe yakınlaşma seviyesini ifade etmektedir (Ateş, 2007: 2-3).

Performans, gerek araştırmacıların gerek yöneticilerin gerekse işgörenlerin üzerinde sıklıkla durduğu temel konulardan biridir. İşletmelerin kurumsal hedeflerine ulaşabilmeleri ve içinde bulundukları sektörde rekabet gücü kazanabilmeleri için yaptıkları işte etkin performans gösteren işgörenlere ihtiyaçları vardır. Etkin performans, işletmeler için olduğu kadar işgörenler açısından da önemlidir (Zincirkıran vd., 2015: 63).

Etkili bir performans değerlendirme sistemi için öncelikle objektif bir performans ölçümüne gereksinim bulunmaktadır. Amaca uygun bir performans ölçüm sisteminin işletmenin başarmak istediği amaçlara uygun, olumsuz motivasyona yol açmayan, ilişkilendirilebilir, iyi tanımlanmış, zamanlı, güvenilir, karşılaştırılabilir ve doğrulanabilir özelliklere sahip olması gerekmektedir (Ateş ve Kırılmaz, 2015: 125). Performans ölçümü ve yönetimi ülkelerin reform gündeminde yer aldığı gibi, hem kamu kurum ve kuruluşlarının hem de işletmelerin kullandığ yönetsel teknik ve araçların başında gelmektedir. Başarının objektif ve adil biçimde ölçülmesine ve performans bilgisinin yönetim süreçlerinde kullanılmasına duyulan ihtiyaç her geçen gün daha da artması nedeniyle performans ölçme ve değerlendirme konusu önem arz etmektedir (Köseoğlu ve Şen, 2014: 132).

Performans bireysel ve örgütsel bazda değerlendirilebilmekte olup bu kavramı oluşturan temel öğe ölçümdür. Performansın ortaya konulmasında etkili olan kriterlerin belirlenmesi ve ölçülmesi bireysel ve örgütsel performansın ortaya konmasını sağlamaktadır (Turunç, 2015: 19). Performans kriterleri, bir kurumun performans hedeflerine ulaşma derecesini ölçmek, değerlendirmek ve izlemek üzere kullanılan araçlardır. Performans kriterleri, stratejik amaç ve hedeflerinin yerine getirilmesinde ulaşılan sonuçları ölçmek için kullanılmaktadır ve performans ölçümüne temel oluşturmaktadır (Ateş ve Köseoğlu, 2011; 36-40).

Performans değerleme kavramı önceleri bireysel performans ağırlıklı kullanılıp, genellikle bireysel performans ölçümü çerçevesinde uygulanılırken artık performans değerlemenin ikinci önemli boyutu olan örgütsel performans değerleme kavramı önem kazanmaya başlamıştır (Turunç, Erkuş ve Polat, 2005: 762).

Örgütsel performans işletmelerin açık bir sistem içerisinde faaliyetlerini sürdürdükleri düşüncesinden yola çıkmaktadır. Örgütsel performans örgütün her kademesini ilgilendiren çok sayıda konu hakkında kararlar alınmasını gerektirmektedir. Bunların başında örgütsel tasarım gelmektedir. Örgüt tasarımının 
gerçekleştirilmesinde ön plana çıan konular arasında işletmenin açık sistem içerisinde faaliyetlerini sürdürüyor olması, örgüt iç tasarımının en modern şekilde gerçekleştirilmesi, örgüt içerisinde her kademedeki çalışanlar arasındaki insan ilişkilerinin geliştirilmesi gibi başlıklar bulunmaktadır (Avcı ve Çınaroğlu, 2015: $5)$.

İşletmeler, ürettikleri mal ya da hizmetin alanı ne kadar farklı olursa olsun, belirli hedeflere ulaşmak ve görevleri gerçekleştirmek için kurulmaktadır. İşletme yöneticilerinin temel görevlerinden biri de; içinde bulundukları örgütün stratejik amaç ve hedeflerini en iyi şekilde gerçekleştirmektir. İşletmelerin temel amaçları ya da misyonları ile stratejik plan ve politikaların gerçekleştirebilmesi ise genel olarak performanslarının belirlenmesiyle ilgilidir. Bununla birlikte, işletme birimlerinin ya da çalışanlarının içinde bulundukları örgütün amaçlarına katkıları da doğrudan birim ya da çalışan performanslarının belirlenmesi ile ortaya konulabilmektedir (Demirsel, 2014: 287).

Örgüt performansı, çevre koşulları ve küreselleşmenin gereklerini yerine getirmenin ve örgütün stratejik amaçlarını gerçekleştirmenin ölçüsü olarak kabul edilmektedir. Örgütsel performans; etkililik, etkenlik, verimlilik, kalite, sürekli iyileştirme, yenilik, iş hayatının kalitesi ve karlılık gibi performans boyutlarının optimal birleşimi sonucunda etkisini gösterecektir (Akın ve Erdost Çolak, 2012: 87).

Örgütsel performans ölçütlerinin geliştirilmesinde kullanılan ilk ayrım ölçütlerin nesnelliğine/öznelliğine dayanır. Öznel örgütsel performans ölçütleri ağırlıklı olarak örgüt üye ve paydaşlarının performansa ilişkin algılarına dayanır ve algılarla amaçlar arasında bir tutarlılık söz konusudur. Nesnel örgütsel performans ölçütleri ise ağırlıklı olarak finansal verilere dayanarak oluşturulan ve herhangi bir algının söz konusu olmadığı karşılaştırmalı verilerdir (Altuntaş ve Dönmez, 2010: 56). Dess ve Robinson (1984: 270), çalışmasında örgütsel performansın değerlendirilmesinde özellikle finansal performansın değerlendirilmesinde öznel ölçütlerin kullanılmaması gerektiğini belirtmiştir.

Finansal/finansal olmayan ölçütler kullanmak da örgütsel performansın ölçülmesinde geliştirilen bir diğer tekniktir. Finansal performans ölçütleri, sıklıkla gelir, nakit akışı, aktif kârlılığı ve özkaynak kârlılığı gibi ölçütlerdir. Performansı değerlendirmek amacıyla kullanılan finansal ölçütler, yararlı olmasına karşın, örgütü tanımlayan ve gerçekleştirdiği farklı faaliyetlerine anlam kazandıran bazı yönetsel eylem ve yeniliklerin finansal kazançlar sağlamaması nedeniyle yeterli değildir (Altuntaş ve Dönmez, 2010: 56).

Finansal olmayan örgütsel performansın kriterleri arasında şunlar sayılabilir (Turunç, Erkuş ve Polat, 2005: 764-765): Amaç birliği, bağımlılık, bilgi yönetimi, çalışan katılımı, denge, fonksiyonlar arası koordinasyon, katılma ve yetkinin paylaşımı, örgütsel iletişim, planlama ve amaçları belirleme, uyumluluk, yöneticilerin işteki ustalığı, yöneticilerin kişiler arası ilişkilerde ustalığı, bilgisayar sistemleri kullanımında gelişim, süreç yenilikleri, teknolojik değişme, ürün çeşitlendirme, ürün farklılaştırma, ürün yenilikleri, yenilik, aşırı devamsızlık durumu, çalışanlar arası ilişkiler, çalışanların becerileri, çalışma yaşamının kalitesi, çatışma, eğitim ve geliştirmeye önem verme derecesi, gönül gücü, insan kaynaklarının değeri, iş tatmini, iş yaşamının kalitesi, işten çıkarma, moral, motivasyon, öğrenme, personel gelişimi, rol ve normların uygunluğu, personel dönüşümü, iş kazaları, atık emniyeti-sorunsuzluğu, dağıtım güvenilirliği, dağıtım performansı, envanter performansı, hacim esnekliği, tedarik süresi liderliği, tedarikçi memnuniyeti, etkililik, etkinlik, genel gider azaltımı, teslim hızı, kaynak kullanım performansı, üretim etkenliği, ürün kalitesi, ürün performansı, maliyet kontrolü, maliyet liderliği, çevreyi kullanma, fiyat liderliği, güvenilirlik, hazır olma, hizmet kalitesi, imaj, kalite, müşteri memnuniyeti, müşteri sadakati, müşteri yönlülük, pazar kalitesi, pazar payı büyümesi, pazar yönlülük, pazara giriş engelleri, rakip yönlülük, yeni pazar, yeni ürün tanıtımı, yoğun pazarlama, yoğunlaşma, satıcı gücü süreç vb. 
Atkinson ve Brown (2001: 129), organizasyonel performansın ölçülmesinde, finansal bakış açısının yanı sıra finansal olmayan ölçütlerin kullanılmasıyla daha bütüncül ve stratejik bir ölçüm gerçekleştirilebileceğini belirtmiştir.

\subsection{Bilgi Teknolojileri Kullanımının Örgütsel Performansa Etkileri}

Küresel rekabet ortamı içinde işletmeler farklı amaç ve beklentilerle BT'nin desteğine ihtiyaç duymaktadır. BT'nin örgütlere sunduğu stratejik avantajların değerlendirilmesinde, bilginin doğru karar vermede ve gelecekle ilgili belirsizliği azaltmada en önemli unsur olduğunun ve bu bilgiyi sağlamada temel rolü üstlendiğinin anlaşılması önemlidir (Güleş, Bülbül ve Çağlıyan, 2003: 65).

Günümüzde işletmelerin rekabetçiliği uzun vadede sürdürülebilir olmasını sağlayan en önemli faktör "bilgi ve bilginin yönetimi”dir. Sağlık sektörü bir yandan çok hızlı gelişen teknolojiler diğer yandan içerisinde bulunduğu yoğun rekabet ortamı nedeniyle çok hızlı bir değişim süreci içerisindedir. Sağlık güvence sistemlerinde sürekli değişimler yaşanmakta, bu durum sağlık kuruluşları ve tedarikçileri arasında daha fazla bilgi akışını gerekli hale getirmektedir. Bu noktada veri, sağlık işletmeleri için en önemli kaynak haline gelmektedir (Bal ve Akgemci, 2011: 756).

Teknolojiyi özellikle de bilişim teknolojilerini kurum içi süreçlerine adapte edebilen işletmeler önemli performans artışları sağlayabilecekler; yeni ürün ve hizmetlerin, yeni iş yollarının, yeni çalışma sistemlerinin ve yeni bilgi edinme yollarının yaratılması gibi faydalar gündeme gelebilecektir. Bu yararlar kurumsal yapıda ise; raporlama işlemlerini kolaylaştırma, işlerin kontrol süresi ve imkânlarının artışı, dinamik yapı için gerekli yetki devri ve güçlendirme uygulamaları, bölümlerin ya da birimlerin yeniden şekillendirilmesi, hedef kitle için coğrafik alanları yeniden tanımlama ve genişletme gibi yansımalara neden olacaktır. Bunlar da ekonomide; eticaret vasıtasıyla pazarlama şeklinin değişimi, aracılığın ortadan kalkması, yeni pazarlama ve reklâm türlerinin ortaya çıkması, yeni iş ortakları bulma ve anlaşmalar yapma imkânı, kurum içi işlemler için maliyetlerin azalması ve müşteri-tedarikçi ilişkileri yönetiminde değişim ve gelişim gibi pek çok yararlar sağlayacaktır (Demirsel, 2014: 280).

BT’nin bir sektördeki rekabet yapısını yeni ürün ve hizmetlerin geliştirilmesi, karar vermenin desteklenmesi, işletmeler arası bağlantıların güçlendirilmesi, maliyetlerin azaltılması, ürün ve hizmetlere BT'nin dâhil edilmesi suretiyle etkilediği söylenebilir (Güleş, Bülbül ve Çağlıyan, 2003: 67).

Bilgi teknolojisi bir işletme performansı olarak daha önce var olmayan bilgiyi yakalama ya da toplama aktiviteleriyle daha fazla bilgi üretmektedir. Bu teknoloji ayrıca daha kapsamlı analiz ve genişletilmiş veriyi kullanmak için alan yaratır. Bir şirketteki değişkenlerin sayısının analizi ya da kontrolü önemli bir şekilde artmaktadir ( Porter ve Millar, 1985: 152).

Oktal ve Özata (2013: 97), yapmış oldukları çalışmada işletmelerde kullanılan bilgi sistemlerinin kullanıcı tatmini sağlayarak örgütsel performansı sağlamada başarılı oldukları sonucuna ulaşmışlardır. Saydam, Mesci ve Kılınç (2014: 163), tarafından yapılan çalışmada; İşgücünün etkin kullanımında bilgi teknolojilerinin önemli ölçüde verimliliği arttırdığı tespit edilmiştir. Yine aynı araştırmada otel işletmelerinin bilgi teknolojileri aracılığıyla daha az işgücü kullanarak daha fazla verimlilik elde ettikleri tespit edilmiştir.

Bülbül, Özçifçi ve Özoğlu (2014: 104) tarafından yapılan çalışmada tedarik zinciri ve işletme performansına bilişim teknolojilerinin etkisi araştırılmış, bilişim teknolojileri ile işletme genel performansı arasında doğrudan bir ilişki bulunmadığı sonucuna varılmıştır. Güleş, Bülbül ve Çağlıyan, (2003: 76) bilişim teknolojileri 
kullanımının işletme performansına etkisini araştırdıkları çalışmada ise, işletme çalışanlarının BT'nin işletme performansını artırdı ğı konusunda ortak görüşe sahip olduklarını belirlemişlerdir.

Işık ve Akbolat (2010: 387) yapmış oldukları çalışmada; sağlık çalışanlarının bilgi sistemlerinin önemine inandığı, hizmet içi eğitim şeklinde bilgi sistemleri konusunda eğitim almakta oldukları ve bilgi teknolojileri kullanımında kendilerini yeterli gördükleri sonucuna ulaşmışlardır. Wanga vd. (2015: 591), bilişim teknolojileri ve firma performansı arasındaki ilişkiyi araştırdıkları çalışmalarında bilgi teknolojileri ve firma performansı arasında direkt bir ilişki bulamadıklarını belirtmişılerdir.

\section{METODOLOJİ}

\subsection{Amaç}

$\mathrm{Bu}$ araştırmanın amacı sağlık personelinin bilgi sistemleri işlevlerini kullanımının örgütsel performansa etkisi olup olmadığını belirlemektir. Bu araştırma ile sağlık personelinin bilgi sistemleri işlevlerini nerelerde kullandığını incelemek, bilgi sistemleri ile örgütsel performans arasındaki ilişkiyi sağlık sektörü üzerinde test etmek amaçlanmaktadır.

\subsection{Evren ve Örneklem}

Araştırma İstanbul ili Pendik ilçesinde bulunan 3 özel hastanede görev yapan sağlık personeli üzerinde yapılmıştır. Basit tesadüfi örnekleme yöntemi kullanılarak araştırmanın örneklemi belirleniştir. Söz konusu özel hastanelerde görev yapan 166 sağlık personeli araştırmanın örneklemini oluşturmaktadır. Sağlık personeline bilgi sistemlerini kullanımlarının örgütsel performanslarına etkisinin olup olmadığına dair sorular sorulmuş ve cevaplar alınmıştır.

\subsection{Veri Toplama Tekniği}

Araştırmada veri toplama tekniği olarak anket yöntemi kullanılmıştır. Veri toplama aracı olarak Özdemir ve Dulkadir (2017) tarafindan BT ve örgütsel performans literatüründen yararlanılarak geliştirilen "Bilgi Teknolojisi İşlevleri Ölçeği”, “Örgütsel Performans Ölçeği” ve sosyo-demografik bilgilerin elde edilmesine yönelik bilgi formu kullanılmıştır. Veri toplama aracında yer alan maddelerin gerçekleşme düzeyini belirlemek için 5'li likert tipi "Kesinlikle Katılıyorum (5)", "Kat1liyorum (4)", "Biraz Katılıyorum (3)", "Katılmıyorum (2)" ve "Kesinlikle Katılmıyorum (1)" dereceleri kullanılmıştır. Yüz yüze anket uygulama yöntemi kullanılmış; katılımcılar sözlü olarak bilgilendirildikten sonra sözlü onamları alınmış ve gönüllülük esasına göre anket yapılmıştır.

\subsection{Verilerin Analizi ve Değerlendirilmesi}

Araştırmada elde edilen veriler bilgisayar ortamına aktarıldıktan sonra SPSS 18.0 paket programında değerlendirilmiştir. Verilen analizi ve değerlendirilmesinde tanımlayıcı istatiksel yöntemler, faktör analizi, güvenilirlik analizi, bağımsız örneklerde t-testi, tek yönlü varyans analizi (anova), korelasyon ve regresyon analizleri yapılmıştır.

\subsection{Araştırmanın Modeli ve Hipotezleri}

Araştırmada BT işlevlerinin örgütsel performans üzerindeki etkileri incelenmiş, ayrıca demografik değişkenlerin BT işlevleri ve örgütsel performans üzerindeki etkisi ortaya konulmuştur. Bu doğrultuda araştırma modeli ve hipotezleri şu şekilde oluşturulmuştur: 


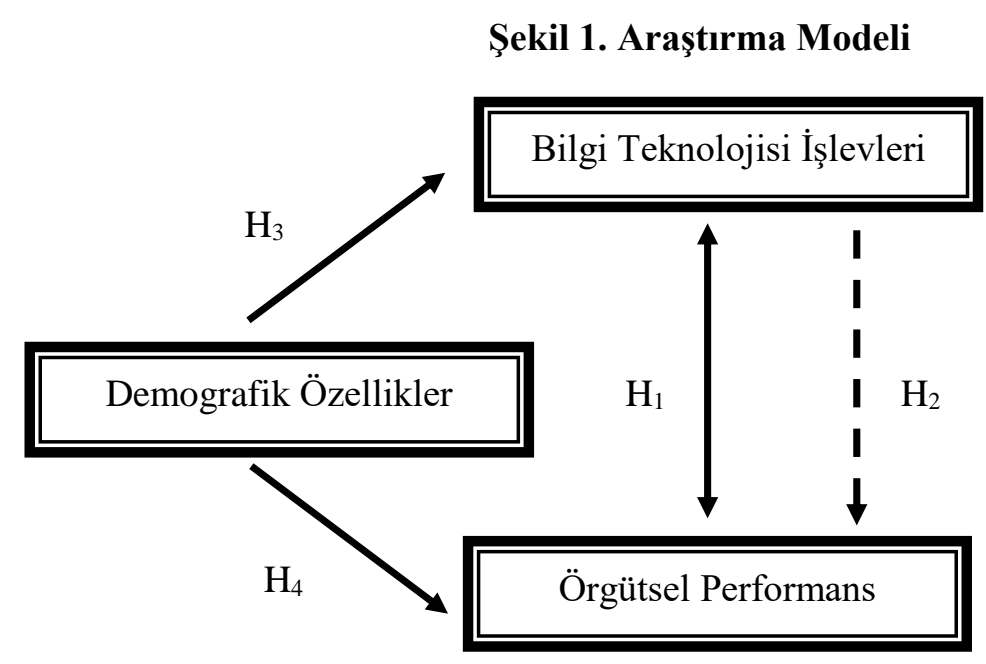

$\mathbf{H}_{1}$ : Bilgi teknolojisi işlevleri ile örgütsel performans üzerinde ilişki vardır.

$\mathbf{H}_{2}$ : Bilgi teknolojisi işlevleri örgütsel performans üzerinde olumlu etkiye sahiptir.

H3: Demografik değişkenlere göre sağlık personelinin bilgi teknolojisi işlevleri kullanım düzeyleri arasında anlamlı fark vardır.

$\mathbf{H}_{4}$ : Demografik değişkenlere göre sağlık personelinin örgütsel performans düzeyleri arasında anlamlı fark vardir.

\subsection{Güvenirlik Analizleri}

Çalışmada BT işlevleri ölçeğinin alt boyutu olan dışsal odaklanma alt boyutunun KMO istatistiği 0,760 olarak bulunmuştur ve bu sonuç veri setine faktör analizi uygulanabileceğini göstermektedir. Faktör analizi varyansını test etmede kullanılan Barlett's test of sphericity sonucu ise $x^{2}=279,331 ; p=0,000$ bulunmuştur. Bu sonuçlar faktör analizinin kabul edilebilirliğini göstermektedir. Ayrıca dışsal odaklaşma faktörünün toplam varyansın \%34,133’ünü açıkladığı, cronbach alpha değerinin ise 0,730 olduğu görülmüştür.

Tablo 1. BT’nin Dışsal Odaklaşma Amaçlı İşlevleri Ölçeğinin Güvenirliği

\begin{tabular}{|c|c|c|c|}
\hline \multicolumn{3}{|c|}{ Kaiser-Meyer-Olkin Measure of Sampling Adequacy. } & 0,760 \\
\hline Bartlett's Test of Sphericity & Anlamlı & Sig. & 0,000 \\
\hline Approx. Chi-Square & 279,331 & Df & 36 \\
\hline Açıklanan Toplam Varyans & 34,133 & Cronbach Alpha & 0,730 \\
\hline \multicolumn{2}{|c|}{ BT'nin Dışsal Odaklaşma Amaçlı İşlevleri } & Faktör Yükü & $\begin{array}{c}\text { Açıklanan } \\
\text { Varyans }\end{array}$ \\
\hline \multicolumn{2}{|c|}{ BT, mevcut ve potansiyel hasta sayısını artırır. } & 0,602 & \multirow{9}{*}{34,133} \\
\hline \multicolumn{2}{|c|}{ BT, sağlık hizmeti kalitesini artırır. } & 0,725 & \\
\hline \multicolumn{2}{|l|}{ BT, verimliliği artırır. } & 0,591 & \\
\hline \multicolumn{2}{|c|}{$\mathrm{BT}$, hastanenin rekabet gücünü artırır. } & 0,447 & \\
\hline \multicolumn{2}{|l|}{ BT, hasta memnuniyetini artırır. } & 0,630 & \\
\hline \multicolumn{2}{|c|}{ BT, sağlık hizmeti sunumunda bekleme süresini azaltır. } & 0,485 & \\
\hline \multicolumn{2}{|c|}{ BT, sağlık hizmeti sunumunda ilaç ve tıbbi sarf malzeme teminini hızlandırır. } & 0,698 & \\
\hline \multicolumn{2}{|l|}{ BT, maliyetleri azaltır. } & 0,460 & \\
\hline \multicolumn{2}{|l|}{ Karar almada etkinlik sağlar. } & 0,552 & \\
\hline
\end{tabular}


BT işlevleri ölçeğinin diğer alt boyutu olan içsel bütünleşme alt boyutunun KMO istatistiği 0,845 bulunmuştur. $\mathrm{Bu}$ sonuç veri setine faktör analizi uygulanabileceğini göstermektedir. Faktör analizi varyansını test etmede kullanılan Barlett's test of sphericity sonucu ise $\mathrm{x}^{2}=646,540 ; \mathrm{p}=0,000$ bulunmuştur. Bu sonuçlar faktör analizinin kabul edilebilirliğine işaret etmektedir. Ayrıca dişsal odaklaşma faktörünün toplam varyansın \%37,411'ini açıkladığ1, cronbach alpha değerinin ise 0,829 olduğu görülmüştür.

Tablo 2. BT’nin İçsel Bütünleşme Amaçlı İşlevleri Ölçeğinin Güvenirliği

\begin{tabular}{|c|c|c|c|}
\hline \multicolumn{3}{|c|}{ Kaiser-Meyer-Olkin Measure of Sampling Adequacy. } & 0,845 \\
\hline Bartlett's Test of Sphericity & Anlamlı & Sig. & 0,000 \\
\hline Approx. Chi-Square & 646,540 & Df & 66 \\
\hline Açıklanan Toplam Varyans & 37,411 & Cronbach Alpha & 0,829 \\
\hline \multicolumn{2}{|c|}{ BT'nin İçsel Bütünleşme Amaçlı İşlevleri } & Faktör Yükü & $\begin{array}{c}\text { Açıklanan } \\
\text { Varyans }\end{array}$ \\
\hline \multicolumn{2}{|c|}{ BT, bilgiye anında ulaşabilmemizi sağlar. } & 0,640 & \multirow{12}{*}{37,411} \\
\hline \multicolumn{2}{|c|}{ BT, hastane ve birimler arasındaki koordinasyonu sağlar. } & 0,679 & \\
\hline \multicolumn{2}{|c|}{ BT, bilginin saklanmasını sağlar. } & 0,650 & \\
\hline \multicolumn{2}{|c|}{ BT, eskimiş bilgileri yenileyip entegre eder. } & 0,680 & \\
\hline \multicolumn{2}{|l|}{ BT, hata yapma olasılığını azaltır. } & 0,479 & \\
\hline \multicolumn{2}{|l|}{ BT, iş süreçlerini standartlaştırır. } & 0,490 & \\
\hline \multicolumn{2}{|c|}{ BT, raporlamanın düzenli yapılmasını sağlar. } & 0,709 & \\
\hline \multicolumn{2}{|c|}{ BT, aynı verilerden farklı raporlar üretilmesini sağlar. } & 0,551 & \\
\hline \multicolumn{2}{|c|}{ BT, e-sağlık ( e-randevu, e-sağlık vb.) desteği sağlar. } & 0,637 & \\
\hline \multicolumn{2}{|l|}{ BT, iletişimin etkinliğini artırır. } & 0,661 & \\
\hline \multicolumn{2}{|l|}{ BT, bilginin güvenliğini sağlar. } & 0,585 & \\
\hline \multicolumn{2}{|l|}{ BT, stok takibini kolaylaştırır. } & 0,523 & \\
\hline
\end{tabular}

Son olarak örgütsel performans ölçeğinin KMO istatistiği ise 0,853 olarak bulunmuştur ve bu sonuç veri setine faktör analizi uygulanabileceğini göstermektedir. Faktör analizi varyansını test etmede kullanılan Barlett's test of sphericity sonucu $\mathrm{x}^{2}=881,448 ; \mathrm{p}=0,000$ bulunmuştur. Bu sonuçlar faktör analizinin kabul edilebilirliğini göstermektedir. Ayrıca dışsal odaklaşma faktörünün toplam varyansın \%42,980'ini açıkladığı, cronbach alpha değerinin ise 0,849 olduğu görülmüştür. 
Tablo 3. Örgütsel Performans Ölçeğinin Güvenilirliği

\begin{tabular}{|c|c|c|c|}
\hline \multicolumn{3}{|c|}{ Kaiser-Meyer-Olkin Measure of Sampling Adequacy. } & 0,853 \\
\hline Bartlett's Test of Sphericity & Anlamlı & Sig. & 0,000 \\
\hline Approx. Chi-Square & 881,448 & $\overline{\text { Df }}$ & 66 \\
\hline Açıklanan Toplam Varyans & 42,980 & Cronbach Alpha & 0,849 \\
\hline \multicolumn{2}{|c|}{ Örgütsel Performans } & Faktör Yükü & $\begin{array}{c}\text { Açıklanan } \\
\text { Varyans }\end{array}$ \\
\hline \multicolumn{2}{|c|}{ BT, hastane işletme maliyetlerini düşürmüştür. } & 0,235 & \multirow{12}{*}{42,980} \\
\hline \multicolumn{2}{|c|}{ BT, hastane iş süreçleri /yöntemlerini geliştirmiştir. } & 0,580 & \\
\hline \multicolumn{2}{|c|}{ BT, hastane veri kaynaklarının daha iyi kullanılmasını sağlamıştır. } & 0,717 & \\
\hline \multicolumn{2}{|c|}{ BT, hastane de örgüt içi iletişimi artırmıştır. } & 0,655 & \\
\hline \multicolumn{2}{|c|}{ BT, hastanenin genel başarısını artırmıştır. } & 0,793 & \\
\hline \multicolumn{2}{|c|}{ BT, hastane birimlerinin başarısını artırmıştır. } & 0,742 & \\
\hline \multicolumn{2}{|c|}{ BT, hastanede örgütsel yenilikleri artırmıştır. } & 0,727 & \\
\hline \multicolumn{2}{|c|}{ BT, hastanenin imajını olumlu yönde etkilemiştir. } & 0,688 & \\
\hline \multicolumn{2}{|c|}{ BT, hastaların hastaneden duyduğu memnuniyeti artırmıştır. } & 0,747 & \\
\hline \multicolumn{2}{|c|}{ BT, hastanenin verimliliğini artırmıştır. } & 0,627 & \\
\hline \multicolumn{2}{|c|}{ BT, hastanenin karlılığını artırmıştır. } & 0,468 & \\
\hline \multicolumn{2}{|c|}{ BT, hastanede sunulan hizmetin kalitesini artırmıștır. } & 0,688 & \\
\hline
\end{tabular}

\section{BULGULAR}

\subsection{Katılımcıların Sosyo-Demografik Özellikleri}

Araştırmaya katılan sağlık çalışanlarının demografik özellikleri Tablo 4'te yer almaktadır. Bu tabloya göre katılımcıların \% 70,5'i (117 kişi) kadın, \% 29,5'i (49 kişi) erkektir. Katılımcıların medeni durumuna baktığımızda \% 50,6'sı (84 kişi) evli, \% 49,4'ü (82 kişi) bekârdır. Katılımcıları yaş bakımından ele aldığımızda, \% 27,7'sinin (46 kişi) 25 yaş ve altında; \% 27,7'sinin (46 kişi) 26-30 yaş arasında; \% 24,7'sinin (41 kişi) 32 39 yaş arasında; \% 19,9'unun (33 kişi) 40 yaş ve üstü olduğu görülmektedir. Katılımcıların eğitim durumu incelendiğinde, \% 22,9'unun (38 kişi) lise; 27,7'isinin (46 kişi) önlisans; \% 25,9'unun (43 kişi) lisans; \% 18,7'sinin (31 kişi) yüksek lisans; \% 4,8'inin (8 kişi) doktora mezunu olduğu görülmektedir. Katılımcıların \% 47,0’1 (78 kişi) A Hastanesinde; \% 36,1’i (60 kişi) B Hastanesinde; \% 16,9’u (28 kişi) C Hastanesinde görev yapmaktadır. 
Tablo 4. Katılımcılara Ait Demografik Özellikler (n: 166)

\begin{tabular}{|c|l|c|c|}
\hline Değişken & \multicolumn{1}{|c|}{ Grup } & Frekans & Yüzde \\
\hline \multirow{4}{*}{ Cinsiyet } & Kadın & 117 & 70,5 \\
\cline { 2 - 4 } & Erkek & 49 & 29,5 \\
\hline \multirow{4}{*}{ Medeni Durum } & Evli & 84 & 50,6 \\
\cline { 2 - 4 } & Bekâr & 82 & 49,4 \\
\hline \multirow{4}{*}{ Yaş } & 25 yaş ve altında & 46 & 27,7 \\
\cline { 2 - 4 } & 26-30 yaş arasında & 46 & 27,7 \\
\cline { 2 - 4 } & 32-39 yaş arasında & 41 & 24,7 \\
\cline { 2 - 4 } & 40 yaş ve üstü & 33 & 19,9 \\
\hline \multirow{4}{*}{ Hastim Durumu } & Lise & 38 & 22,9 \\
\cline { 2 - 4 } & Önlisans & 46 & 27,7 \\
\cline { 2 - 4 } & Lisans & 43 & 25,9 \\
\cline { 2 - 4 } & Yüksek Lisans & 31 & 18,7 \\
\cline { 2 - 4 } & Doktora & 8 & 4,8 \\
\hline & A Hastanesi & 78 & 47,0 \\
\cline { 2 - 4 } & B Hastanesi & 60 & 36,1 \\
\cline { 2 - 4 } & C Hastanesi & 28 & 16,9 \\
\hline
\end{tabular}

\subsection{Sosyo Demografik Özelliklere Göre Farklılıkların İncelenmesi}

Çalışmanın bu bölümünde katılımcıların cinsiyet, medeni durum, yaş, eğitim durumu ve hastane farklılıklarını incelemek amacıyla bağımsız örneklerde t testi ve tek yönlü varyans analizi bulgularına yer verilmiştir.

Demografik değişkenlere göre farklılıkların incelenmesi sonucunda cinsiyetin BT işlevleri ve örgütsel performans ile farklılık oluşturup oluşturmadığını incelemek amacıyla bağımsız örneklerde $t$ testi analizi yapılmıştır (Tablo 5). Yapılan analiz sonucunda, katılımcıların erkek ya da kadın olmalarının BT işlevleri ve örgütsel performans üzerinde bir farklılık oluşturmadığı görülmüştür ( $p>0,05)$.

Tablo 5. Cinsiyet Değişkenine Göre Farklılıkların İncelenmesi

\begin{tabular}{|c|c|c|c|c|c|c|}
\hline & Cinsiyet & $\mathbf{N}$ & Ortalama & $\begin{array}{c}\text { Standart } \\
\text { Sapma }\end{array}$ & f & $\mathbf{p}$ \\
\hline \multirow[b]{2}{*}{ BT'nin Dışsal Odaklaşma Amaçlı İşlevleri } & Kadın & 117 & 4,31 & 0,418 & \multirow[b]{2}{*}{0,001} & \multirow[b]{2}{*}{0,378} \\
\hline & Erkek & 49 & 4,25 & 0,422 & & \\
\hline \multirow{2}{*}{ BT’nin İçsel Bütünleşme Amaçlı İşlevleri } & Kadın & 117 & 4,28 & 0,482 & \multirow{2}{*}{4,964} & \multirow{2}{*}{0,161} \\
\hline & Erkek & 49 & 4,17 & 0,388 & & \\
\hline \multirow{2}{*}{ Örgütsel Performans } & Kadın & 117 & 4,40 & 0,437 & \multirow{2}{*}{1,797} & \multirow{2}{*}{0,792} \\
\hline & Erkek & 49 & 4,38 & 0,399 & & \\
\hline
\end{tabular}

Demografik değişkenlere göre farklılıkların incelenmesi sonucunda medeni durumun BT işlevleri ve örgütsel performans ile farklılık oluşturup oluşturmadığını incelemek amacıyla bağımsız örneklerde t testi analizi 
yapılmıştır (Tablo 6). Yapılan analiz sonucunda, katılımcıların evli ya da bekâr olmalarının BT işlevleri ve örgütsel performans üzerinde bir farklılık oluşturmadığı görülmüştür ( $p>0,05)$.

Tablo 6. Medeni Durum Değişkenine Göre Farlılıkların İncelenmesi

\begin{tabular}{|c|c|c|c|c|c|c|}
\hline & $\begin{array}{l}\text { Medeni } \\
\text { Durum }\end{array}$ & $\mathbf{N}$ & Ortalama & $\begin{array}{c}\text { Standart } \\
\text { Sapma }\end{array}$ & $\mathbf{f}$ & $\mathbf{p}$ \\
\hline \multirow[b]{2}{*}{ BT'nin Dışsal Odaklaşma Amaçlı İşlevleri } & Evli & 84 & 4,26 & 0,422 & \multirow[b]{2}{*}{0,120} & \multirow[b]{2}{*}{0,363} \\
\hline & Bekâr & 82 & 4,32 & 0,415 & & \\
\hline \multirow{2}{*}{ BT'nin İçsel Bütünleşme Amaçı İşlevleri } & Evli & 84 & 4,27 & 0,431 & \multirow{2}{*}{0,607} & \multirow{2}{*}{0,564} \\
\hline & Bekâr & 82 & 4,22 & 0,486 & & \\
\hline \multirow{2}{*}{ Örgütsel Performans } & Evli & 84 & 4,43 & 0,405 & \multirow{2}{*}{1,068} & \multirow{2}{*}{0,215} \\
\hline & Bekâr & 82 & 4,35 & 0,443 & & \\
\hline
\end{tabular}

Katılımcıların yaşlarının BT işlevleri ve örgütsel performans açısından farklılık oluşturup oluşturmadığını belirlemek amacıyla tek yönlü varyans analizi yapılmıştır (Tablo 7). Yapılan analiz sonucunda katılımcıların yaşları ile BT’nin içsel bütünleşme amaçlı işlevleri alt boyutu ve örgütsel performans arasında anlamlı fark bulunamamıştır ( $>0,05)$. Diğer taraftan katılımcıların yaşları ile BT’nin dışsal odaklaşma amaçlı işlevleri alt boyutu arasında anlamlı farklılık tespit edilmiştir $(\mathrm{p}<0,05)$.

Tablo 7. Yaş Değişkenine Göre Farklılıkların İncelenmesi

\begin{tabular}{|c|c|c|c|c|c|c|c|}
\hline & Yaş & $\mathbf{N}$ & Ortalama & $\begin{array}{l}\text { Standart } \\
\text { Sapma }\end{array}$ & f & $\mathbf{p}$ & Post-Hoc \\
\hline \multirow{4}{*}{$\begin{array}{c}\text { BT’nin } \\
\text { Dışsal } \\
\text { Odaklaşma } \\
\text { Amaçlı } \\
\text { İşlevleri }\end{array}$} & 25 yaş ve altı (1) & 46 & 4,401 & 0,403 & \multirow{4}{*}{3,030} & \multirow{4}{*}{$0,031^{*}$} & \multirow{4}{*}{$\begin{array}{c}1-2 \\
p<0,05\end{array}$} \\
\hline & 26-30 yaş arası (2) & 46 & 4,15 & 0,446 & & & \\
\hline & $32-39$ yaş arası (3) & 41 & 4,29 & 0,399 & & & \\
\hline & 40 yaş ve üstü (4) & 33 & 4,36 & 0,386 & & & \\
\hline \multirow{4}{*}{$\begin{array}{c}\text { BT’nin } \\
\text { İçsel } \\
\text { Bütünleşme } \\
\text { Amaçlı } \\
\text { İşlevleri }\end{array}$} & 25 yaş ve altı (1) & 46 & 4,25 & 0,510 & \multirow{4}{*}{0,472} & \multirow{4}{*}{0,702} & \\
\hline & $26-30$ yaş arası (2) & 46 & 4,18 & 0,464 & & & \\
\hline & 32-39 yaş arası (3) & 41 & 4,27 & 0,417 & & & \\
\hline & 40 yaş ve üstü (4) & 33 & 4,29 & 0,430 & & & \\
\hline \multirow{4}{*}{$\begin{array}{c}\text { Örgütsel } \\
\text { Performans }\end{array}$} & 25 yaş ve altı (1) & 46 & 4,35 & 0,455 & \multirow{4}{*}{1,280} & \multirow{4}{*}{0,283} & \\
\hline & $26-30$ yaş arası (2) & 46 & 4,32 & 0,425 & & & \\
\hline & 32-39 yaş arası (3) & 41 & 4,45 & 0,356 & & & \\
\hline & 40 yaş ve üstü (4) & 33 & 4,47 & 0,453 & & & \\
\hline
\end{tabular}

Katılımcıların eğitim durumlarının BT işlevleri ve örgütsel performans açısından farklılık oluşturup oluşturmadığını belirlemek amacıyla tek yönlü varyans analizi yapılmıştır (Tablo 8). Yapılan analiz sonucunda 
katılımcıların eğitim durumları ile BT işlevleri ve örgütsel performans arasında anlamlı fark bulunamamıştır $(\mathrm{p}>0,05)$.

Tablo 8. Eğitim Değişkenine Göre Farklılıkların İncelenmesi

\begin{tabular}{|c|c|c|c|c|c|c|}
\hline & Eğitim Durumu & $\mathbf{N}$ & Ortalama & $\begin{array}{c}\text { Standart } \\
\text { Sapma }\end{array}$ & $\mathbf{f}$ & $\mathbf{p}$ \\
\hline \multirow{5}{*}{$\begin{array}{c}\text { BT'nin Dışsal Odaklaşma } \\
\text { Amaçlı İşlevleri }\end{array}$} & Lise & 38 & 4,28 & 0,432 & \multirow{5}{*}{0,498} & \multirow{5}{*}{0,737} \\
\hline & Önlisans & 46 & 4,34 & 0,422 & & \\
\hline & \begin{tabular}{|l|} 
Lisans \\
\end{tabular} & 43 & 4,28 & 0,410 & & \\
\hline & Yüksek Lisans & 31 & 4,23 & 0,416 & & \\
\hline & Doktora & 8 & 4,42 & 0,451 & & \\
\hline \multirow{5}{*}{$\begin{array}{c}\text { BT’nin İçsel Bütünleşme } \\
\text { Amaçlı İşlevleri }\end{array}$} & Lise & 38 & 4,26 & 0,569 & \multirow{5}{*}{0,407} & \multirow{5}{*}{0,804} \\
\hline & Önlisans & 46 & 4,30 & 0,389 & & \\
\hline & \begin{tabular}{|l|} 
Lisans \\
\end{tabular} & 43 & 4,23 & 0,433 & & \\
\hline & Yüksek Lisans & 31 & 4,18 & 0,471 & & \\
\hline & Doktora & 8 & 4,19 & 0,367 & & \\
\hline \multirow{5}{*}{ Örgütsel Performans } & Lise & 38 & 4,35 & 0,462 & \multirow{5}{*}{0,298} & \multirow{5}{*}{0,879} \\
\hline & Önlisans & 46 & 4,43 & 0,389 & & \\
\hline & Lisans & 43 & 4,36 & 0,433 & & \\
\hline & Yüksek Lisans & 31 & 4,40 & 0,408 & & \\
\hline & Doktora & 8 & 4,45 & 0,534 & & \\
\hline
\end{tabular}

Çalışanların görev yaptığı hastane ile BT işlevleri ve örgütsel performans açısından farklılık oluşturup oluşturmadığını belirlemek amacıyla tek yönlü varyans analizi yapılmıştır (Tablo 9). Yapılan analiz sonucunda katılımcıların görev yaptığı hastane ile BT'nin içsel bütünleşme amaçlı işlevleri alt boyutu arasında anlamlı fark bulunamamıştır ( $\mathrm{p}>0,05)$. Diğer taraftan katılımcıların görev yaptığı hastane ile BT’nin dışsal odaklaşma amaçlı işlevleri alt boyutu ve örgütsel performans arasında anlamlı farklılık tespit edilmiştir $(\mathrm{p}<0,05)$. Buna göre B Hastanesinde görev yapan katılımcıların, A Hastanesinde görev yapan kat1lımcılara oranlar \%4,27 daha fazla BT'nin dışsal odaklaşma amaçlı işlevlerini benimsedikleri; C Hastanesinde görev yapan katılımcıların A Hastanesinde görev yapan katılımcılara oranla \%6,03 daha fazla örgütsel performansa önem verdikleri görülmektedir. Diğer bir ifadeyle, A Hastanesinde görev yapan katılımcıların bilgi teknolojileri ve örgütsel performans konularına daha az önem verdiğini söylemek mümkündür.

Tablo 9. Hastane Değişkenine Göre Farklılıkların İncelenmesi

\begin{tabular}{|c|c|c|c|c|c|c|c|}
\hline & Hastane & $\mathbf{N}$ & Ortalama & $\begin{array}{l}\text { Standart } \\
\text { Sapma }\end{array}$ & $\mathbf{f}$ & $\mathbf{p}$ & Post-Hoc \\
\hline \multirow{3}{*}{$\begin{array}{c}\text { BT'nin Dışsal Odaklaşma Amaçlı } \\
\text { İşlevleri }\end{array}$} & A Hastanesi & 78 & 4,22 & 0,398 & \multirow{3}{*}{3,445} & \multirow{3}{*}{$0,034^{*}$} & \multirow{3}{*}{$\begin{array}{c}\text { A-B } \\
p<0,05\end{array}$} \\
\hline & B Hastanesi & 60 & 4,40 & 0,438 & & & \\
\hline & C Hastanesi & 28 & 4,28 & 0,395 & & & \\
\hline \multirow{3}{*}{$\begin{array}{c}\text { BT’nin İçsel Bütünleşme Amaçlı } \\
\text { İşlevleri }\end{array}$} & A Hastanesi & 78 & 4,18 & 0,466 & \multirow{3}{*}{1,828} & \multirow{3}{*}{0,164} & \\
\hline & B Hastanesi & 60 & 4,27 & 0,488 & & & \\
\hline & C Hastanesi & 28 & 4,37 & 0,338 & & & \\
\hline \multirow{3}{*}{ Örgütsel Performans } & A Hastanesi & 78 & 4,31 & 0,375 & \multirow{3}{*}{4,131} & \multirow{3}{*}{$0,018^{*}$} & \multirow{3}{*}{$\begin{array}{c}\text { A-C } \\
\mathrm{P}<0,05\end{array}$} \\
\hline & B Hastanesi & 60 & 4,41 & 0,491 & & & \\
\hline & C Hastanesi & 28 & 4,57 & 0,350 & & & \\
\hline
\end{tabular}




\subsection{Bilgi Teknolojileri ve Örgütsel Performans İlişkisi}

Çalışmanın bu bölümünde BT işlevleri ile örgütsel performans arasındaki ilişkiyi ve BT işlevlerinin örgütsel performansa etkisini incelemek amacıyla korelasyon ve regresyon analizi bulgularına yer verilmiştir. BT işlevleri ile örgütsel performans arasındaki ilişki pearson korelasyon analizi ile incelenmiştir (Tablo 10). Analiz sonucuna göre BT'nin dışsal odaklaşma amaçlı işlevleri ile BT'nin içsel bütünleşme amaçlı işlevleri arasında $\left(\mathrm{r}=, 566^{* *}\right)$ pozitif yönde ve yüksek düzeyde bir ilişki, BT'nin dışsal odaklaşma amaçlı işlevleri ve örgütsel performans arasında $\left(r=, 555^{* *}\right)$ pozitif yönde ve yüksek düzeyde bir ilişki, BT’nin içsel bütünleşme amaçlı işlevleri ve örgütsel performans arasında $\left(\mathrm{r}=, 523^{* *}\right)$ pozitif yönde ve yüksek düzeyde bir ilişki bulunmuştur.

Tablo 10. Bilgi Teknolojisi İşlevleri ve Örgütsel Performans İlişki

\begin{tabular}{|cc|c|c|c|}
\hline & & $\begin{array}{c}\text { BT'nin Dışsal } \\
\text { Odaklaşma } \\
\text { Amaçlı İşlevleri }\end{array}$ & $\begin{array}{c}\text { BT'nin İçsel } \\
\text { Bütünleşme Amaçlı } \\
\text { İşlevleri }\end{array}$ & $\begin{array}{c}\text { Örgütsel } \\
\text { Performans }\end{array}$ \\
\hline BT'nin Dışsal Odaklaşma & Pearson Correlation & 1 &, $566^{* *}$ &, $555^{* *}$ \\
Amaçlı İşlevleri & Sig. (2-tailed) & - &, 000 &, 000 \\
BT'nin İçsel Bütünleşme & $\mathrm{N}$ & 166 & 166 & 166 \\
\cline { 2 - 5 } Amaçlı İşlevleri & Pearson Correlation &, $566^{* *}$ & 1 &, $523^{* *}$ \\
& Sig. (2-tailed) &, 000 & - &, 000 \\
Örgütsel Performans & $\mathrm{N}$ & 166 & 166 & 166 \\
\cline { 2 - 5 } & Pearson Correlation &, $555^{* *}$ &, $523^{* *}$ & 1 \\
& Sig. (2-tailed) &, 000 &, 000 & - \\
& $\mathrm{N}$ & 166 & 166 & 166 \\
\hline
\end{tabular}

Correlation is significant at the 0.01 level (2-tailed).

Regresyon analizi sonucunda BT'nin dışsal odaklaşma amaçlı işlevlerinin örgütsel performans ile yüksek düzeyde ve anlamlı bir ilişkiye sahip olduğu bulunmuştur $\left(R=0,555 ; R^{2}=0,308 ; p<0,001\right)$. Regresyon analizi sonucuna göre BT'nin dışsal odaklaşma amaçlı işlevleri örgütsel performansın toplam varyansının \%30,8'ini açıklamaktadır. Standardize edilmiş beta katsayısı ve t değerleri incelendiğinde BT'nin dışsal odaklaşma amaçlı işlevlerinin örgütsel performansı anlamlı bir şekilde etkilediği söylenebilir $(\mathrm{t}=8,547 ; \mathrm{p}<0,001)$. Sonuç olarak kurulan modelin anlamlı olduğu görülmektedir $(\mathrm{F}=73,058 ; \mathrm{p}<0,001)$ (Tablo 11).

Tablo 11. BT'nin Dışsal Odaklaşma Amaçıı İşlevlerinin Örgütsel Performansa Etkisi

\begin{tabular}{|c|c|c|c|c|c|}
\hline \multirow{2}{*}{ Model } & \multicolumn{2}{|c|}{$\begin{array}{c}\text { Standardize } \\
\text { Edilmemiş } \\
\text { Katsayılar }\end{array}$} & $\begin{array}{c}\text { Standardize } \\
\text { Edilmiş } \\
\text { Katsaylar }\end{array}$ & \multirow{2}{*}{$\mathbf{p}$} & \\
\cline { 2 - 5 } Sabit & 1,973 & 0,284 & $\boldsymbol{\beta}$ & & \\
\hline Örgütsel Performans & 0,563 & 0,066 & 0,555 & 8,547 & 0,000 \\
\hline R: 0,555 & \multicolumn{2}{|c|}{ F: 73,058} & p: 0,000 \\
\hline
\end{tabular}

a Predictors (Bağımsız Değişkenler): (Sabit), Örgütsel Performans

b Dependent Variable (Bağımlı Değişken): BT’nin Dışsal Odaklaşma Amaçlı İşlevleri 
Regresyon analizi sonucunda BT'nin içsel bütünleşme amaçlı işlevlerinin örgütsel performans ile yüksek düzeyde ve anlamlı bir ilişkiye sahip olduğu görülmüştür $\left(R=0,523 ; R^{2}=0,274 ; p<0,001\right)$. Regresyon analizi sonucuna göre BT'nin içsel bütünleşme amaçlı işlevleri örgütsel performansın toplam varyansının \%27,4'ünü açıklamaktadır. Standardize edilmiş beta katsayısı ve t değerlerine bakıldığında BT'nin içsel bütünleşme amaçlı işlevlerinin örgütsel performansı anlamlı bir şekilde etkilediği söylenebilir $(t=7,865 ; p<0,001)$. Bu durumda kurulan modelin anlamlı olduğu görülmektedir $(\mathrm{F}=61,853 ; \mathrm{p}<0,001)$ (Tablo 12).

Tablo 12: BT’nin İçsel Bütünleşme Amaçlı İşlevlerinin Örgütsel Performansa Etkisi

\begin{tabular}{|c|c|c|c|c|c|}
\hline \multirow{2}{*}{ Model } & \multicolumn{2}{|c|}{$\begin{array}{c}\text { Standardize } \\
\text { Edilmemiş } \\
\text { Katsayılar }\end{array}$} & $\begin{array}{c}\text { Standardize } \\
\text { Edilmiş } \\
\text { Katsayılar }\end{array}$ & $\mathbf{t}$ & $\mathbf{p}$ \\
\cline { 2 - 4 } & $\boldsymbol{\beta}$ & Std. Hata & $\boldsymbol{\beta}$ & & \\
\hline Sabit & 2,330 & 0,264 & & 8,838 & 0,000 \\
\hline Örgütsel Performans & 0,486 & 0,062 & 0,523 & 7,865 & 0,000 \\
\hline R: 0,523 & $\mathbf{R}^{2}: 0,274$ & F: 61,853 & p: 0,000 \\
\hline
\end{tabular}

a Predictors (Bağımsız Değişkenler): (Sabit), Örgütsel Performans

b Dependent Variable (Bağımlı Değişken): BT’nin İçsel Bütünleşme Amaçlı İşlevleri

\section{SONUÇ}

Son yıllarda teknoloji alanında yaşanan hızlı gelişmeler organizasyonları ve onların bilgi teknolojileri kullanımlarını etkilemiştir. Günümüzde organizasyonlar daha fazla bilgi teknolojileri kullanmakta ve iş yapma süreçlerini ve organizasyon örgütlenmelerini bu bilgi teknolojileri çerçevesinde yeniden yapılandırmaktadırlar. Sağlık işletmelerinin bilgi teknolojilerinde yaşanan bu değişiklikleri yakından takip ettikleri ve organizasyonlarına adapte ettikleri görülmektedir. Sağlık işletmeleri tarafından; online randevu, hasta kaydı, sonuçların görüntülenmesi, görüntüleme teknikleri, hasta memnuniyetinin arttırılması, hasta bilgilerinin depolanması, çalışanlara yönelik eğitim, örgüt içi ve örgüt dışı iletişim vb. birçok alanda bilgi teknolojiler yoğun bir şekilde kullanılmaktadır. Bu bağlamda bu çalışma sağlık çalışanlarının bilgi sistemi işlevleri kullanımlarının örgütsel performansa olan etkilerini ortaya koyabilmek amacıyla yapılmıştır.

Yaş değişkenine göre; katılımcıların örgütsel performans, BT’nin dışsal odaklaşma amaçlı işlevleri ve içsel bütünleşme amaçlı işlevlerinden etkilenmelerinde anlamlı farklılık olup olmadığı araştırılmıştır. Yapılan analiz sonucunda, yaş ile örgütsel performans ve içsel bütünleşme amaçlı işlevleri arasında anlamlı bir farklılık bulunamamıştır. Ancak yaş ile BT'nin dışsal odaklaşma amaçlı işlevleri arasında anlamlı bir farklılık bulunmuştur. $\mathrm{Bu}$ farklılık 25 yaş ve altı katılımcılar ile 26-30 yaş arasındaki katılımcıların ilişkiden kaynaklanmaktadır (Tablo 7). 25 yaş ve altı katılımcıların BT’nin dışsal odaklaşma amaçlı işlevlerine karşı algılarının 26-30 yaş aralığındaki katılımcıların algılarına göre daha yüksek olduğu görülmektedir.

Eğitim durumu değişkenine göre; katılımcıların, örgütsel performans, BT'nin dışsal odaklaşma amaçlı işlevleri ve içsel bütünleşme amaçlı işlevlerinden etkilenmelerinde anlamlı farklılık olup olmadığı incelenmiş yapılan analiz sonucunda, eğitim durumu ile örgütsel performans, BT'nin dışsal odaklaşma amaçlı işlevleri ve içsel bütünleşme amaçlı işlevleri arasında anlamlı bir farklılık bulunamamıştır (Tablo 8).

Katılımcıların çalışmakta oldukları hastane ile BT işlevleri ve örgütsel performans açısından farklılık oluşturup oluşturmadığını araştırılmış (Tablo 9). Yapılan analiz sonucunda katılımcıların çalışmakta oldukları hastane ile 
BT'nin içsel bütünleşme amaçlı işlevleri alt boyutu arasında anlamlı fark bulunamamıştır. Ancak katılımcıların çalışmakta oldukları hastane ile BT'nin dışsal odaklaşma amaçlı işlevleri alt boyutu ve örgütsel performans arasında anlamlı farklılık tespit edilmiştir. Dışsal odaklaşma amaçlı işlevlerin algılanmasında B hastanesinde çalışanların algı düzeylerinin A hastanesinde çalışanlara göre daha yüksek olduğu bulunmuştur. Ayrıca C hastanesinde görev yapmakta olan çalışanların örgütsel performans algısının A hastanesinde çalışanlara göre daha yüksek olduğu belirlenmiştir.

Örgütsel performans, BT'nin dışsal odaklaşma amaçlı işlevleri ve BT'nin içsel bütünleşme amaçlı işlevleri arasında anlamlı bir ilişski olup olmadığı korelasyon analizi ile araştırılmıştır(Tablo 10). Yapılan analiz sonucunda, BT'nin içsel bütünleşme amaçlı işlevleri ile BT'nin dışsal odaklaşma amaçlı işlevleri arasında pozitif yönde, anlamlı, çok güçlü bir ilişki bulunmuştur. Örgütsel performans ve BT'nin dişsal odaklaşma amaçlı işlevleri arasında pozitif yönde, anlamlı, çok güçlü bir ilişki bulunmuştur. Örgütsel performans ve BT'nin içsel bütünleşme amaçlı işlevleri arasında pozitif yönde, anlamlı, çok güçlü bir ilişki bulunmuştur. Bilgi teknolojilerinin örgüt içi kullanımı ile örgüt dışı kullanımı ve örgütsel performans birbirini etkilemektedir. Bilgi teknolojilerinin örgüt içindeki kullanımı ve örgüt dışındaki kullanımı ile örgütsel performansın birbirini etkilemesi nedeniyle örgütsel performans arttırmak amacıyla örgütlerin daha fazla bilgi teknolojileri kullanımları teşvik edilebilir.

BT’nin dişsal odaklaşma amaçlı işlevlerinin örgütsel performansa etkisinin ölçümü için regresyon analizi yapılmıştır (Tablo 11). Analiz sonucunda BT'nin dışsal odaklaşma amaçlı işlevleri örgütsel performansı pozitif yönde etkilemektedir. Buna göre BT’nin dışsal odaklaşma amaçlı işlevlerinin kullanımı sonucunda örgütsel performans üzerinde etkili bir artış gözlenecektir.

Yapılan çalışmadan elde edilen veriler ışı̆̆ında; bilgi teknolojilerinin dışsal odaklaşma amacıyla kullanımı ile mevcut ve potansiyel hasta sayısını artırılması, sağlık kalitesindeki artış, verimliliğin artması, hastanenin rekabet gücündeki artma, hasta memnuniyetinde artış, sağlık hizmeti sunumu esnasındaki bekleme sürelerinin azaltılması, sağlık hizmeti sunumundaki ilaç ve tıbbi malzeme teminindeki hızlanma, maliyetlerin azalması ve karar almadaki etkinlik sağlanabilmekte ve bunlar da örgütsel performansın artmasına katkı sağlamaktadır.

BT’nin içsel bütünleşme amaçlı işlevlerinin örgütsel performansa etkisi ölçümü için regresyon analizi yapılmıştır (Tablo 12). Analiz sonucunda BT’nin içsel bütünleşme amaçlı işlevleri örgütsel performansı pozitif yönde etkilemektedir. Bilgi teknolojilerin içsel bütünleşme amacıyla kullanımı sayesinde; bilgiye daha hızlı ulaşılabilmekte, hastane ve birimler arasında koordinasyon sağlanabilmekte, bilgi saklanması gerçekleştirilebilmekte, eskimiş sistemler yenilenip entegrasyon sağlanabilmekte, hata yapma olasılıkları azalmakta, iş yapma süreçleri standardize edilebilmekte, raporlamalar düzenli bir şekilde yapılabilmekte, aynı verilerden farklı veri üretimi yapılabilmekte, e-randevu ve e-sonuç işlemleri gerçekleştirilebilmekte, örgüt içinde daha etkili iletişim sağlanmakta, bilgi güvenliği ve stok takibi yapılabilmektedir. Bütün bunlar örgütsel performansın artmasına katkı sağlamaktadır.

Sonuç olarak, hastanelerde işletme maliyetlerini düşürülmesi, iş süreçlerinin-yöntemlerinin geliştirilmesi, hastane veri kaynaklarının daha iyi kullanılması, örgüt içi iletişimin artması, kalite, akreditasyon vb. yeniliklere ayak uydurulması, hastanenin imajını olumlu yönde etkilenmesi, hasta memnuniyetinin artması, verimlilik ve karlılık artışının sağlanması, kaliteli hizmet sunumun sağlanması gibi birçok nedenden dolayı örgütlerin bilgi teknolojileri kullanmalarını arttırmaları örgütsel performans artırımına katkı sağlayacaktır. 


\section{KAYNAKÇA}

Akın, Ö. ve Erdost Çolak, H. E. (2012), "İnsan Kaynakları Yönetimi Uygulamalarıyla Örgütsel Performans Arasındaki İlişki Üzerine Bir Araştırma”, Çankırı Karatekin Üniversitesi İktisadi ve İdari Bilimler Fakültesi Dergisi, Cilt 2, Say1 2, ss. 85-114.

Altuntaş, G. ve Dönmez, D. (2010), “Girişimcilik Yönelimi ve Örgütsel Performans İlişkisi: Çanakkale Bölgesinde Faaliyet Gösteren Otel İşletmelerinde Bir Araştırma”, İstanbul Üniversitesi Işsletme Fakültesi Dergisi, Cilt 39, Say1 1, ss. 50-74.

Ateş, H. ve Kırılmaz, H. (2015), "Sağl1k Personelinin Performans Yönetimine İlişkin Görüşleri Üzerinde Kişisel Faktörlerin Etkileri”, Amme İdaresi Dergisi, Cilt 48, Sayı 4, ss. 97-128

Ateş, H. (2007), "Kavramlar, Tartışmalar, Genel Çerçeve", içinde Ateş, Kırılmaz ve Aydın (ed.), Sağllk Sektöründe Performans Yönetimi Türkiye Örneği, Ankara: Asil Yayın Dağıtım, ss. 1-20.

Ateş, H. ve Köseoğlu, Ö. (2011), Belediyelerde Kurumsal Performans Yönetimi, İstanbul: İlke Yayıncılık.

Atkinson, H. ve Brown, J. B. (2001), "Rethinking Performance Measures: Assessing Progress in UK Hotels", International Journal of Contemporary Hospitality Management, Cilt 13, Say1 3, ss. 128-135.

Avc1, K., ve Çınaroğlu, S. (2015), "Sağlık Bakanlığı Hastaneleri’nin Örgütsel ve Finansal Performans Göstergeleri Bakımından Kümelenmesi”, Hacettepe Üniversitesi İktisadi ve İdari Bilimler Fakültesi Dergisi, Cilt 33, Sayı 2, ss. 1-23.

Bal, C. G. ve Akgemci, T. (2011), "Bilişim Teknolojilerinin Üniversite Hastanelerinde Kullanımının Farklı Değişkenler Açısından İncelenmesi”, Gaziantep Üniversitesi Sosyal Bilimler Dergisi, Cilt 10, Sayı 2, ss. 749 759.

Bensghir, T. K. (1996), Bilgi Teknolojileri ve Örgütsel Değişim, Ankara: Türkiye ve Orta Doğu Amme İdaresi Enstitüsü.

Bingöl, D. (2006), Insan Kaynakları Yönetimi, İstanbul: Arıkan Basım Yayım Dağıtım.

Bülbül, H., Özçifçi, V. ve Özoğlu, B. (2014), "Tedarik Zinciri ve İşletme Performansına Bilişim Teknolojilerinin Etkisi”, Niğde Üniversitesi IIIBF Dergisi, Cilt 7, Sayı 1, ss. 95-106.

Demirsel, M. T. (2014), “KOBİ'lerde Kullanılan Bilişim Teknolojilerinin Örgütsel Performansa Etkileri: Konya Organize Sanayi Bölgelerinde Bir Araştırma”, Selçuk Üniversitesi İktisadi ve İdari Bilimler Fakültesi Sosyal ve Ekonomik Araştırmalar Dergisi, Cilt 14, Sayı 28, ss. 278-305.

Dess, G. G. ve Robinson, R. B. JR. "Measuring Organizational Performance in the Absence of Objective Measures: The Case of the Privately-held Firm and Conglomerate Business Unit", Strategic Management Journal, 1984, 5, ss. 265-273.

Elibol, H. (2005), "Bilişim Teknolojileri Kullanımının İşletmelerin Organizasyon Yapıları Üzerindeki Etkileri”, Selçuk Üniversitesi Sosyal Bilimler Enstitüsü Dergisi, Cilt 13, ss. 155-162.

Güleş, H. K., Bülbül, H. ve Çağlayan, V. (2003), "Bilişim Teknolojileri Kullanımının İşletme Performansına Etkisi: Küçük ve Orta Ölçekli Sanayi İşletmelerinde Bir Uygulama”, Selçuk Üniversitesi İIBF Ekonomik Araştırmalar Dergisi, Cilt 6, ss. 61-83.

Işık, O. ve Akbolat, M. (2010), "Bilgi Teknolojileri ve Hastane Bilgi Sistemleri Kullanımı: Sağlık Çalışanları Üzerine Bir Araştırma”, Bilgi Dünyası, Cilt 11, Sayı 2, ss. 365-389. 
İraz, R. (2004), “Organizasyonlarda Karar Verme ve İletişim Sürecinin Etkinliği Bakımından Bilgi Teknolojilerinin Rolü”, Selçuk Üniversitesi Sosyal Bilimler Enstitüsü Dergisi, Cilt 11, ss. 407-422.

Köseoğlu, Ö. ve Şen, M. L. (2014), "Kamu Sektöründe Performans Yönetimi: Politikalar, Uygulamalar ve Sorunlar”, Akademik Incelemeler Dergisi, Cilt 9, Say1 2, ss. 113-136.

Oktal, Ö. ve Özata, F. Z. (2013), "Bilgi Sistemleri Başarısında Örgütsel Performansı Etkileyen Değişkenlerin İncelenmesi”, İstanbul Management Journal, Cilt 24, Say1 74, ss. 86-101.

Özdemir, F. (2011), "Yığışım İşletmelerinde Rekabet Üstünlüğü Sağlamada Bilişim Teknolojilerinin Etkisi: Mermer Sektörü Örneği”, Süleyman Demirel Üniversitesi Vizyoner Dergisi, Cilt 3, Sayı 5, ss. 148-172.

Özdemir, L. ve Dulkadir, B. (2017), "Bilişim Teknolojisi İşlevlerinin Örgütsel Performans Üzerine Etkisi”, Yönetim Bilimleri Dergisi, Cilt 15, Say1 29, ss. 25-41.

Porter, M. E. ve Millar, V. E. (1985), "How Information Gives You Competitive Advantage", Harvard Business Review, July-August, ss. 149-174.

Reddy, S. B. (2006), "Strategic Flexibility and Information Technology Properties: Competitive Advantage And Asset Specificity”, ACR, Cilt 14, Say1 1, ss. 16-43.

Saydam, R., Mesci, M. ve Kılınç, İ. (2014), "Bilgi Teknolojilerinin İşletme Performansına Etkileri: Konya Otelleri Örneği”, C.Ü. İktisadi ve İdari Bilimler Dergisi, Cilt 15, Sayı 1, ss. 151-169.

Tekin, M., Zerenler, M., ve Bilge, A. (2005), "Bilişim Teknolojileri Kullanımının İşletme Performansına Etkileri: Lojistik Sektöründe Bir Uygulama”, İstanbul Ticaret Üniversitesi Fen Bilimleri Dergisi, Cilt 4, Say1 8, ss. 115-129.

Turan, A. H. (2009), “Küçük ve Orta Büyüklükteki İşletmelerde (KOBİ) Bilişim Teknolojileri (BT), Örgütsel Rekabetçi Stratejileri ve Başarım İlişkisi”, Atatürk Üniversitesi İktisadi ve İdari Bilimler Dergisi, Cilt 23, Sayı 3, ss. 105-122.

Turunç, Ö. (2015), "Stratejik Yönetim Örgütsel Performans İlişkisinde Kişi-Örgüt Uyumunun Rolü”, Uluslararası Íktisadi ve İdari Bilimler Dergisi, Cilt 1, Say1 1, ss. 16-30.

Turunç, Ö., Erkuş, A. ve Polat, M. (2005), “İşletmelerde Örgütsel Performansın Değerlendirilmesinde NicelNitel Kriterler: Savunma Sanayiinde Bir Araştırma”, 15. Ulusal Yönetim ve Organizasyon Kongresi, ss. 761768.

Yıldız, M. S. (2008), “Küçük ve Orta Ölçekli İşletmelerde (KOBİ) Bilgi Teknolojilerinin Kullanım Düzeyi ve Bilgi Teknolojilerinin Firmalar Üzerindeki Etkileri”, Elektronik Sosyal Bilimler Dergisi, 2008, Cilt 7, Sayı 25, ss. 212-239.

Zincirkıran, M., Çelik Mat, G., Ceylan, A. K ve Emhan, A. (2015), “İşgörenlerin Örgütsel Bağl1lık, İşten Ayrılma Niyeti, İş Stresi ve İş Tatmininin Örgütsel Performans Üzerindeki Etkisi: Enerji Sektöründe Bir Araştırma”, Finans Politik \& Ekonomik Yorumlar, Cilt 52, Sayı 600, ss. 59-71.

Wang, Y., Shi, S., Nevo, S., Li, S., Chen, Y. (2015), “The Interaction Effect of IT Assets and IT Management on Firm Performance: A Systems Perspective”, International Journal of Information Management, Cilt 35, ss. 580-593. 